\title{
Terra de ninguém: escravidão e direito natural no jovem Joaquim Nabuco
}

\author{
Ricardo Benzaquen de Araújo*
}

\section{RESUMO}

O texto em pauta pretende se concentrar na análise do primeiro livro redigido por Joaquim Nabuco, $A$ escravidão, no qual ele relata a sua experiência na defesa de um escravo julgado por crimes de morte em Pernambuco em 1869. Ao sustentar sua argumentaçáo em uma dura crítica do cativeiro, formulada no contexto da tradição do Direito Natural, e na discussão de questóes vinculadas aos conceitos de propriedade, fetichismo e despotismo, além de uma consideração da noção escolástica de pessoa, Nabuco torna possível não só um diálogo entre a teologia medieval e o liberalismo moderno, como também a preservaçáo da vida do seu constituinte, que acaba tendo a sua pena comutada para a de prisão perpétua.

Palavras-chave: Joaquim Nabuco; escravidão; Direito Natural; propriedade; despotismo.

\section{ABSTRACT}

This paper focuses on the analysis of the first book written by Joaquim Nabuco, $A$ escravidão (Slavery), in which he relates his experience in defending a slave accused of murder in 1869 in Pernambuco. Nabuco grounds his argument on a severe critique of bondage, formulated in the context of the Natural Law tradition. Debating issues pertaining to the concepts of property, fetishism, and despotism, in addition to a consideration of the scholastic notion of personhood, he not only brings about a dialogue between medieval theology and modern liberalism, but also the preservation of his defendant's life, who ends up having his sentence commuted to life imprisonment.

Keywords: Joaquim Nabuco; slavery; Natural Law; property; despotism.

DOI - http://dx.doi.org/10.1590/2237-101X0173202

Artigo recebido em 26 de novembro de 2015 e aprovado para publicação em 3 de fevereiro de 2016.

* Professor-associado 1 da PUC-Rio - Rio de Janeiro, RJ, Brasil e bolsista de produtividade em pesquisa nível

2 do CNPq.

Versões anteriores deste texto foram apresentadas e discutidas na PUC-Rio, em seminários organizados pelo Departamento. de História e pelo Decanato em Ciências Sociais, no PACC da Faculdade de Letras-UFRJ e no XII Congresso Luso-Afro-Brasileiro, realizado na Faculdade de Ciências Sociais e Humanas da Universidade Nova de Lisboa, Portugal. Quero agradecer aos colegas pelo estímulo e pelas sugestôes que, mesmo quando não consideradas agora, serão de grande importância para o desenvolvimento da investigaçáo em curso. 
A trajetória de Joaquim Nabuco, político de destaque, líder abolicionista e um dos mais importantes e criativos intelectuais brasileiros da sua época, praticamente se confunde com a discussão das mais significativas questôes que atravessaram a nossa sociedade entre meados do século XIX e o início do XX. No que se refere à sua relaçâo com a vida do espírito, contudo, sua reputação parece estar fundamentalmente baseada em um conjunto de obras elaboradas na década de 90 daquele século — exceto $O$ abolicionismo, de 1884 —, como a biografia do seu pai, Um estadista do império, seu livro de memórias, Minha formação, e alguns outros títulos supostamente menos relevantes.

Este artigo, todavia, vincula-se, em linhas gerais, a uma pesquisa que pretende se concentrar na outra ponta da sua existência, levando em consideração uma série de trabalhos que ele escreve ainda muito jovem, recém-formado ou perto de concluir o curso de Direito, como A escravidão, de 1870, Le Droit au Meurtre e Camóes e os Lusíadas, ambos de 1872, e a sua polêmica com José de Alencar - além de algumas entradas do seu Diário referentes ao começo dos anos 1870. Redigidos por um autor que, nascido em 1849, contava entâo com vinte e poucos anos, esses textos apresentam evidentemente um certo afastamento no que diz respeito aos estudos que ele vai produzir posteriormente, embora também possam ser notados alguns pontos de contato, quase surpreendentes, entre eles.

No entanto, parece-me que seria extremamente prematuro tentar explorar as semelhanças e diferenças que poderiam ser estabelecidas entre estes livros iniciais e aqueles que ele virá a publicar mais tarde. Mais do que isso, na verdade: a minha sensação é a de que mesmo a comparação entre os textos que Nabuco elabora no começo da década de 1870 deve ser deixada para um próximo momento, no qual o cotejo entre eles tenha condiçốes de ser realizado sem que se sacrifique o que há de singular, complexo e matizado em cada um deles.

O que pretendo fazer aqui, então, é esboçar uma análise daquele que seria o seu primeiro livro, o já mencionado A escravidão, de 1870. Diga-se, de imediato, que este trabalho articula-se com uma experiência da qual o próprio Nabuco participa, pois, retornando ao Recife em 1869 para ali concluir a faculdade de Direito, ele se envolve em 1870 - aos 21 anos, portanto - com a história do escravo Tomás, acusado de dois crimes de morte: considerado culpado pelo assassinato de uma "autoridade" de Olinda, que ele julgava responsável pelo fato de ter sido "barbaramente amarrado e açoitado... [em] praça pública" (p. 41), ${ }^{1}$ ele havia sido transferido, já condenado à morte, para a Detenção do Recife. Daí tenta fugir, e acaba por cometer um segundo assassinato, de um guarda que tentava impedi-lo, delito pelo qual, novamente encarcerado, a promotoria pede que ele receba uma segunda pena de morte.

Nabuco aceita defender Tomás, consegue salvar a sua vida, comutando a pena para a de "galés perpétuas", e logo depois decide escrever $A$ escravidão, dando conta não só de detalhes do caso, mas também, e sobretudo, da argumentação por ele utilizada, a qual, ao rejeitar

\footnotetext{
${ }^{1}$ A partir de agora, todas as passagens entre aspas, salvo se houver menção explícita à sua fonte, serão retiradas de A escravidão (1989), de Joaquim Nabuco.
} 
de forma veemente e sistemática o cativeiro, termina por convertê-lo em uma circunstância atenuante dos crimes cometidos pelo escravo.

No entanto, é necessário observar, antes de prosseguir, que este livro jamais foi publicado durante a vida de Nabuco. O manuscrito, doado em 1924 por sua viúva, Evelina Nabuco, ao Instituto Histórico e Geográfico Brasileiro, só veio à luz, na Revista do IHGB, em 1951, tendo conhecido novas ediçóes em 1988 e 1999. Sem ter condiçôes de discutir as razóes que impediram o nosso autor de imprimir este título, não quero deixar de lembrar que, mesmo mantendo-o inédito, Nabuco nunca se desfez inteiramente dos seus argumentos - como ocorreu com outras reflexóes e textos, sobretudo literários, "cometidos" na mesma época. Ao contrário, $A$ escravidão permaneceu vivo, fornecendo questóes que serão ampliadas e transformadas em obras posteriores, em especial o já citado $O$ abolicionismo, de 1884 , e a Campanha abolicionista no Recife, de 1885.

Mas já é hora de começar a examinar, com o cuidado possível, os termos pelos quais a escravidão é discutida neste texto inicial de Nabuco. Ora, como já foi mencionado, ela é atacada de maneira particularmente dura desde o primeiro parágrafo, inapelavelmente responsabilizada pelo atraso material e, acima de tudo, pela decadência moral das sociedades a ela associadas. Uma crítica deste tipo, sem dúvida, pode em nossos dias parecer fácil e quase banal, mas vale a pena recordar que, somente dois anos antes, em 1868, um autor do porte de José de Alencar havia publicado as suas Novas cartas politicas de Erasmo, destinadas ao imperador e onde se pode perceber uma defesa bastante articulada do cativeiro (cf. Parron in Alencar, 2008).

Voltando a Nabuco, importa enfatizar que o seu argumento não deixa de lembrar que a escravidão "gerou direitos", "direitos civis" (p. 3) e positivos, ou seja, direitos consignados na legislação do império, nem — pior ainda —, passando do plano jurídico para o social, que se trata de

uma instituição que aderiu ao nosso país desde que ele acordou para a vida: foi quase contemporânea do seu descobrimento, foi regada nas raízes por geraçóes inteiras: o egoísmo, o interesse, a ambição, o cinismo atentaram-na, fecundaram-na, em cada torrão de nosso solo caiu uma semente sua, cada fonte de nossa produção saiu de seu grande manancial, o rendimento nacional como o rendimento público são sua seiva. (p. 4)

O problema, evidentemente, reside no fato de que aqueles direitos civis e a própria sociedade que eles conformaram atentam decisivamente contra a "moral [e os] direitos naturais" (p. 3). Surge aqui, já no começo do texto, o ponto sobre o qual Nabuco irá sustentar a base da sua reflexão: a ideia de direito natural, de remota ascendência greco-romana, mas que será profundamente alterada pela tradição cristã e pelos debates intelectuais que marcaram a época moderna. ${ }^{2}$

\footnotetext{
${ }^{2}$ Acerca das diversas correntes envolvidas com a noçáo de direito natural, em uma bibliografia praticamente incomensurável, tomo a liberdade de mencionar o livro de Tierney (2001).
} 
Existem, sem dúvida, inúmeras concretizaçóes diferentes desta síntese, mas, em particular no que se refere a Nabuco, a minha impressão é a de que o cultivo das virtudes clássicas, justiça, temperança, coragem e sabedoria, aliado à defesa de ideais cristãos como os de fé, esperança e sobretudo caridade, irão constituir uma espécie de contexto, uma moldura capaz de garantir o direito à liberdade e à igualdade entre todos os homens, pontos-chave do direito natural moderno. Além disso, ainda cabe lembrar que Nabuco também costuma ser apontado como o mais sólido e profundo pensador liberal do seu tempo, legítimo herdeiro dos argumentos iluministas que, ao longo dos séculos XVII e XVIII, teriam ajudado a forjar a modernidade ocidental. Sem pretender necessariamente discordar desta definição, creio, porém, que ela precise ser cuidadosamente qualificada, inclusive porque basta uma rápida avaliação de trabalhos como $A$ escravidão para que se perceba que o diálogo do nosso autor com a teologia medieval, em especial com a escolástica, parece influenciar decisivamente a sua leitura de Locke, Kant e outros intelectuais de extração iluminista. ${ }^{3}$

Vale a pena assinalar, contudo, que uma perspectiva como esta, longe de se restringir ou concentrar em Nabuco, conhece uma longa e complexa história, na qual posiçóes intelectuais muito diversas articulam-se de maneira original e extremamente sofisticada. Dessa forma, só para dar um exemplo - embora bastante eloquente —, basta uma rápida vista d'olhos na seçấo 5 do capítulo 2 do Segundo tratado sobre o governo, de Locke, um dos textos fundadores do liberalismo seiscentista, para que se torne claro que, ao lado de conceitos como liberdade e igualdade, absolutamente incontornáveis para o entendimento do ocidente moderno, pode-se também encontrar o elogio de categorias como a justiça e a caridade, a primeira referida à herança clássica e a segunda, claro, associada ao advento do Cristianismo.

Retornando a Nabuco, é preciso observar que o fato de ele adotar uma posição até certo ponto comparável a que acabou de ser mencionada não só implica alguma convergência em sua obra entre o direito natural clássico e o moderno como também - e sobretudo - fornece-lhe um instrumento que atravessa de ponta a ponta a argumentaçáo que ele desenvolve em $A$ escravidão, conferindo força, ou melhor, coerência e densidade ao conjunto do seu raciocínio. Para ilustrar esta questão, tornando-a mais clara, pode-se examinar brevemente dois casos levantados na primeira parte do livro: as críticas que ele endereça ao modo pelo qual a escravidão se relaciona tanto com a religiáo cristã — tal como esta se desenvolveu no Brasil — quanto com a noção de propriedade.

No que diz respeito ao primeiro ponto, a escravidáo descaracteriza inteiramente o próprio cristianismo praticado no Brasil, corrompendo a tal ponto a igreja católica que ela termina por contribuir para a formação de uma atmosfera de egoísmo, desesperança e incerteza que, desde a sua fundação, dá a impressão de definir o país.

\footnotetext{
${ }^{3}$ Sobre a relação entre o pensamento de Locke e as diferentes concepçôes que constituem a tradição do direito natural, pode-se consultar os trabalhos de Dunn (1969) e Tully (1993).
} 
Esta corrupção se dá por intermédio de dois caminhos bem distintos, ainda que absolutamente complementares. No primeiro deles, percebe-se uma igreja inteiramente cúmplice da escravidão, preocupando-se, não em condenar, mas, ao contrário, em participar ativamente do regime senhorial, transformando-se inclusive em uma grande proprietária de escravos (p. 12). Esta conduta, por si só, já seria extremamente grave. Para Nabuco, porém, o pior problema irá surgir naquele que era apontado há pouco como o segundo caminho da longa história que vincula a igreja católica à promoção do cativeiro. E este problema resume-se ao completo descaso revelado pela igreja no que se refere à formação ética e religiosa dos africanos aqui reduzidos à escravidão.

Antes de prosseguir, entretanto, creio que se faça necessário um ligeiro desvio para que melhor se compreenda a posiçáo adotada pelo nosso autor acerca desta questão. Senão, vejamos: ao chamar a atençáo para a necessidade de que a igreja dispensasse uma formação cristá aos escravos, quer dizer, que ela cuidasse da sua catequese e consequente civilizaçấo, ele assume decididamente uma perspectiva bem distante daquelas que envolviam qualquer idealização das sociedades e culturas não europeias, como, só para dar um exemplo, aqueles argumentos, de natureza iluminista, que poderiam aproximar os africanos cativos no Brasil da figura do "bom selvagem".

Em vez disso, Nabuco busca entender a sua lógica específica pelo recurso a uma figura, igualmente oriunda do Esclarecimento setecentista, mas que já incorporava — antecipando certo evolucionismo típico do período vitoriano - o que poderíamos chamar de uma concepção moderna de diferença e de desigualdade entre os homens. Refiro-me aqui, em uma palavra, à ideia de "fetichismo". Importando, como ele mesmo afirma, em uma avaliação que vê "nas imagens não o símbolo, mas a substância do ente superior" (p. 9-10), o fetichismo dispersava e personalizava o sagrado em diferentes objetos materiais, definidos como a força motriz em condiçôes de controlar todos os acontecimentos, desejados ou não (cf. Pietz, 2005).

A sorte, o destino dos seres humanos, passava portanto a depender totalmente dos caprichos de uma imensa variedade de entidades materiais, encontráveis um pouco por toda a parte no mundo natural, mas dotadas de um poder até certo ponto misterioso e incontrolável, que convertia a existência em algo marcado pela surpresa, pelo capricho e pela mais absoluta imprevisibilidade.

Trata-se, como se pode ver, de uma religião do medo, não do perdão, e será precisamente ela que, combinada com os aspectos mais exteriores do cristianismo, dará origem ao que Nabuco denomina, durante praticamente todo o livro, de "fetichismo católico". Incapazes de compreender o significado espiritual dos símbolos e ritos cristãos, em função mesmo do já mencionado descompromisso da igreja no que diz respeito a sua formação, os escravos africanos passarão a considerá-los como fetiches: "o batismo para eles, é a água; o matrimônio, a junção das mãos; Deus é o barro [e] Jesus é o crucifixo” (p. 10). 
Assim, para retomar o fio da argumentação, a igreja e o regime senhorial conseguem simplesmente agravar, acentuar o caráter supersticioso das crenças de origem africana, e é justamente aqui que o adjetivo "moderno", utilizado de modo aparentemente descuidado, parágrafos acima, para caracterizar o sistema de valores embutido na noção de fetichismo, ganha todo o seu sentido: esta noção pode ser descrita, como faz o nosso autor, como uma superstição, mas ele próprio nos avisa que nenhuma superstição deve ser compreendida como se fosse um destino, uma fatalidade, um traço constitutivo da natureza humana. Muito ao contrário, e é por esta razão que a diferenciação e a desigualdade atribuídas ao fetichismo podem ser definidas como modernas, tal superstição pode perfeitamente ser superada pelo recurso à educação, pela ênfase e pela recuperação dos direitos naturais -, patrimônio de todos os homens -, o que é precisamente aquilo que a igreja nunca se interessou em fazer.

Já no que se refere ao modo pelo qual a escravidáo se relaciona com a ideia de propriedade, Nabuco vai salientar que

a escravidáo viola da maneira a mais completa o direito de propriedade: $1^{\circ}$ porque estende o domínio a entes livres, $2^{\circ}$ porque tira o direito natural de propriedade aos entes que escraviza. [Entretanto,] como [é que] se legitima a propriedade? Por ser ela um direito do homem naturalmente cercado de dificuldades, e habilitado para vencê-las. (p. 6)

Mas qual é o sentido específico que a ideia de habilidade assume neste contexto? A resposta a esta indagaçấo passa pelo entendimento do homem como um ser dotado de uma "organização deficiente", virtualmente incapaz de sobreviver se não tivesse recebido certas faculdades, como a sensibilidade e a inteligência que, inclusive porque só podem ser exercidas no "mundo exterior", tornam possível a própria conquista deste mundo. Tais faculdades, dessa forma, irão compor uma seção da alma que, indissoluvelmente associada ao corpo, aperfeiçoa-se apenas pelo contato com a experiência externa: assim como o homem só descobre os seus sentidos por intermédio desta experiência - o ouvido pelo som, o olfato pelo odor etc. —, a inteligência só se desenvolve quando se concretiza em uma propriedade, sustentáculo dessa existência mundana do homem. ${ }^{4}$

Ora, se estamos lidando com um conceito de propriedade que se baseia no direito natural, não é à toa que Nabuco, ainda que reconheça a enorme relevância do processo de ocupação da terra, não tenha nenhuma dúvida em descartá-lo como um instrumento por intermédio do qual fosse possível se conseguir a legitimação desta mesma propriedade. Afinal, como ele próprio salienta,

\footnotetext{
${ }^{4}$ Uma reconstituição de boa parte dos debates ocidentais sobre a noção de propriedade é muito bem feita pelo trabalho de Garnsey.
} 
A ocupação é o sinal de nossa precedência na posse: iguais todos os homens no direito às coisas, é minha a que eu adquiro primeiro, por essa razão de igualdade, que não exclui, antes consagra, o direito de precedência... mas como a ocupação só se legitima pela aplicação das faculdades, não basta que se ocupe para se adquirir: de tal sorte o primeiro homem teria ocupado e adquirido a terra. (p. 7)

É exatamente aqui, a propósito, que reside a principal dificuldade do nosso autor com a conexão entre propriedade e ocupação: como nos lembra Locke mais uma vez, a ideia de liberdade, pedra de toque do direito natural moderno, só pode ser defendida se ela implicar uma espécie de harmonia entre a autopreservação individual e a preservação de toda a espécie humana. Neste sentido, o

estado de liberdade (...) não é um estado de licenciosidade; embora o homem nesse estado tenha uma liberdade incontrolável para dispor de sua pessoa ou posses, não tem liberdade para destruir-se ou a qualquer criatura em sua posse, a menos que um uso mais nobre que a mera conservação desta o exija. O estado de natureza tem para governá-lo uma lei da natureza, que a todos obriga; e a razão, em que essa lei consiste, ensina a todos aqueles que a consultem que, sendo todos iguais e independentes, ninguém deveria prejudicar a outrem em sua vida, saúde, liberdade ou posses. Pois sendo todos os homens artefato de um mesmo criador onipotente e infinitamente sábio, todos eles servidores de um senhor soberano e único, enviados ao mundo por Sua ordem e para cumprir Seus desígnios, são propriedade de Seu artífice, feitos para durar enquanto a Ele aprouver, e não a outrem. (cf. Locke, 2005, p. 384-385)

Desse modo, qualquer privilégio concedido à figura do "primeiro ocupante" como uma maneira de fundamentar a noção de propriedade pode, simplesmente, pôr em risco aquela simetria preconizada por Locke - e por Nabuco. Através da ênfase na ocupação, por conseguinte, a sociedade passaria então a ser comparável, na clássica metáfora de inspiração ciceroniana, à plateia de um grande teatro no qual, pelo já mencionado "direito de precedência", aqueles que chegassem primeiro ganhariam condiçóes de ocupar todo o espaço disponível, sem nenhuma preocupação pelo que poderia suceder com os demais espectadores (cf. Tully, 1993).

Tenho a impressão, na verdade, de que as questóes examinadas nos últimos parágrafos talvez possam nos ajudar a começar a entender por que é fundamentalmente o conceito de trabalho - e não o de ocupação - que termina por se converter, de fato, na mais importante categoria utilizada por Nabuco no seu afã em conferir pertinência e autoridade à noção de propriedade. Basta ver que, à relativa desqualificação da ideia de precedência, estreitamente associada a sua capacidade de introduzir o desequilíbrio e a instabilidade na vida social, irá corresponder o veemente elogio daquelas "faculdades" que permitiam ao homem, mesmo cercado de desafios, superar as suas deficiências e se impor ao mundo. 
Tais faculdades, ao contrário da lógica vinculada ao processo de ocupação da terra, não envolvem automaticamente a promoção da desarmonia, da contingência e da imprevisibilidade entre os homens, mas, ao contrário, a afirmação de uma possível — ainda que frágil - compatibilidade entre os limites individuais e a conservação da espécie. Pois bem, parece ser exatamente isto que o destaque do trabalho pode permitir, na medida mesmo em que, "cunho da individualidade, [ele] muda o objeto exterior em uma continuação de nós mesmos, [e] lança um reflexo de nossa soberania individual sobre aquilo que marca o sinal de nossa atividade" (p. 7), povoando, contagiando por este caminho o mundo da experiência com a moralidade e a virtude que, em princípio, parecem orientar aquelas nossas faculdades. É precisamente este cenário, quase bíblico, no qual Locke e São Tomás de Aquino dão a impressão de se encontrar, que a escravidão, pela transformaçáo de alguns homens em propriedade de outros, irá destruir.

Toda esta reflexáo, com efeito, pode ser aprofundada se dedicarmos um pouco mais de cuidado ao alcance e a profundidade que Nabuco empresta ao conceito de "faculdades". E é exatamente isto que ele vai fazer em um dos capítulos de $A$ escravidão, o de número 4, que começa pelo exame do fato de que "a escravidáo degrada a alma do escravo e do senhor" (p. 18). Ele inicia o seu raciocínio afirmando que

nada [é] mais parecido com a alma de um senhor do que a de um escravo. Quereis ver o paralelo? Considerando sempre perante o ideal de justiça, o que é mais degradante - a baixeza deste ou a altivez daquele? $\mathrm{O}$ que fica deprimido num, cresce no outro: são duas molas, uma desce quando a outra sobre; a um vício corresponde outro, os extremos tocam-se. O que afronta mais a justiça [,] o obedecer um ou o mandar o outro? O que é mais degradante, o servilismo ou o despotismo, a covardia do medo ou a covardia da força, açoitar ou ser açoitado? (p. 19)

O tom da sua análise, entretanto, sofre uma modificação e torna-se mais crítico quando ele passa a discutir, no mesmo capítulo, a relação que pode ser estabelecida entre "A Escravidâo e a Filosofia”. Retomando um argumento já empregado por ocasião da sua análise do recém-mencionado vínculo entre a escravidão e a propriedade, Nabuco salienta que o homem implica uma combinação do corpo com a alma, partes distintas mas totalmente inseparáveis de uma mesma identidade. Composto de matéria, de "limo", ele é "posto no mundo misto de uma parte como ele perecível e de um sopro divino" que faz com que, "parte da divindade, o homem náo viv[a] só na terra" (p. 19), ou seja, viva também junto à eternidade, em outro mundo.

Contudo, sua própria alma vai também se dividir em duas seções, a primeira — a única que foi discutida até agora —, responsável pela "sensação [e pela inteligência, que] é a alma vivendo no meio externo, [e a segunda, pelo] pensamento [, que] é a alma vivendo no absoluto" (p. 20). E é justamente esta segunda dimensão da alma, a um só tempo mais interior 
e mais espiritual, que "parece divinizar-se, pensando nessas ideias sublimes, que Deus que é sua personificação depôs em germe indistinto em todos os homens" (Idem).

Não se deve estranhar, por conseguinte, que seja concedida precisamente ao espírito, a parte mais racional da alma, uma espécie de dignidade superior. Afinal, é justamente por seu intermédio, isto é, através dos “olhos da intuição" (p. 20), que a sensibilidade e o corpo conseguem se vincular com as "grandes ideias absolutas", formando uma unidade complexa mas indivisível que "faz com que o homem, rei da criação pela inteligência, seja a obra-prima de Deus pelo pensamento" (Idem). ${ }^{5}$

Não é casual, então, que seja exatamente sobre a atividade intelectual do homem que venha a incidir a mais pesada carga lançada pelo regime senhorial:

A escravidão, pois, condenando ao obscurantismo o espírito, rouba-lhe a vida: mata-o. Não é já só o assassinato do corpo, pelo trabalho e pelos castigos; não é só o assassinato da alma [quer dizer, da sua parte sensível, que liga o corpo à razão,] pela superstição e pela perversidade, é também o assassinato do espírito porque impede-lhe a vida do outro mundo, a vida no absoluto, a vida do pensamento. (p. 21)

Aniquilando o espírito, arruinando a sensibilidade e animalizando o corpo, a escravidão dá origem, dessa forma, a uma ordem social marcada pela mais absoluta imoralidade, pelo mais completo desrespeito ao conjunto sistemático de direitos que os homens receberam de Deus.

E é justamente este caráter antiético e antinatural que Nabuco irá enfatizar quando decide sintetizar o cotidiano dos cativos em um capítulo, de número seis (p. 27-34), sugestivamente intitulado "A escravidão e a caridade". Aqui, em um mundo irremediavelmente distante tanto da caridade quanto da fé e da esperança — sem mencionar as virtudes clássicas e modernas - ele nos apresenta, em rápida e quase hipnótica sucessão, uma série de curtos esboços que se referem quer a personagens significativos deste mundo, como a mãe, o pai e os filhos escravos, quer a distintos períodos da vida de todos eles, "os primeiros anos", "a corrupção da criança” e "a vida", até chegar à morte e ao cemitério.

Talvez fosse melhor não citar, por desnecessário, mas não quero deixar de comentar que a aparente leveza e a velocidade com que se atravessa essas páginas estão distantes de importar em qualquer descaso ou afastamento do nosso autor em relação ao mundo que ele se ocupa em analisar. Longe disso, a minha impressão é a de que o próprio ritmo da leitura, algo vertiginoso, cria um ambiente no qual os diferentes detalhes apresentados por Nabuco:

\footnotetext{
${ }^{5} \mathrm{O}$ exame da noção de pessoa no contexto da filosofia cristá da Idade Média pode ser encontrado, em uma primeira abordagem, no livro clássico de Gilson, Étienne. (2006). Além disso, em especial no que diz respeito à contribuição de São Tomás de Aquino para o debate desta questáo, vale a pena uma consulta ao trabalho de Wéber (1991).
} 
"o escravo, feto ainda, estremece[ndo] nas contorções da mãe sob o chicote" (p. 28), [a escrava,] de quinze a dezesseis anos, às vezes antes... entregue, já violada, às senzalas” (p. 32), [onde é] atirada de um para outro, nos bacanais de todos os dias... [para] vive[r] entre partos e suplícios" (Idem), [sempre para] "engrossar o patrimônio” (p. 28)

do senhor, todos esses detalhes, digamos assim, terminam por perder a sua especificidade e se reunir em um quadro, mais geral, balizado pelo mais completo despotismo, pela sujeição de todos os cativos à vontade, aos caprichos do proprietário.

É dentro desse contexto, por fim, que surge o relato do caso que vincula Nabuco ao "preto Tomás". Vale a pena registrar, antes de mais nada, que a trajetória pregressa de Tomás não se encaixa de forma nenhuma no ambiente até agora delineado pelo nosso autor. De fato, educado como um ser livre, ele supostamente desconhecia os hábitos fetichistas cultivados por outros escravos, ao mesmo tempo que transmitia a sensação de não ter sido exposto ao despotismo inerente à escravidão. Era, por todas essas razóes, "circunspecto, econômico, humilde [e] brioso", desfrutando, por conseguinte, "de uma reputação excelente" (p. 41) em Olinda.

Sucede porém que,

um dia (...), ausente ou morta a senhora mandaram açoitá-lo (...) na praça pública, na roda dos moradores de um lugar pequeno, onde de ordinário todos afluem a qualquer espetáculo, foi ele barbaramente amarrado e açoitado. Fez-se uma reação no caráter do escravo. De humilde tornou-se altivo: era bom, fez-se uma fera. Fugiu com um bacamarte decidido a uma cruel vingança. Suspeitava ele que uma autoridade fora a causa dos açoites... Matou-a com um tiro à queima-roupa. Preso e processado, foi condenado à morte. Como o juiz apelasse por força da lei, foi recolhido à Detenção do Recife. Não era mais um homem, era um tigre que se tinha debaixo de ferros. Mesmo acorrentado era terrível. Aconteceu que lhe deixassem a porta aberta: evadiu-se. O guarda, um pobre Honorato de Bastos quis prendê-lo na fuga, e ele descarregou um golpe para trás, que feriu a Honorato na região anterior do pescoço: depois de precauçóes da polícia, compareceu perante o júri do Recife para responder por mais um homicídio, pois do ferimento do guarda resultou-lhe a morte. O promotor esmerilhou uma circunstância do art. 192 para pedir a pena de morte. Pedia-se a morte para um homem já condenado a ela! (p. 41-42).

O que poderia, nesta situação, nosso jovem advogado fazer? Encontrar circunstâncias atenuantes que lhe permitissem pedir, não a libertação do réu, mas, pelo menos, a comutação da sua pena para a de prisão perpétua, o que obviamente lhe salvaria a vida. Ora, todos os argumentos levantados por Nabuco acerca da escravidão, brevemente discutidos nas páginas anteriores, parecem efetivamente em condiçóes de serem utilizados na defesa de Tomás, em 
particular se nos lembrarmos que, até o momento dramático em que sofre o "flagelo do açoite", ele se conduzia de maneira perfeitamente equilibrada e racional: "trabalhava para a sua senhora e para si com estímulo e consciência. Era chamado em Olinda - o Sr. Tomás” (p. 41).

Mas, e no que se refere à segunda acusação de que ele é objeto, isto é, ao assassinato do guarda Honorato de Bastos? Neste momento, torna-se claro para o leitor que o livro em pauta enfrenta não somente um, mas dois "crimes sociais", posto que Nabuco também condena - asperamente — a adoçáo da pena de morte, lidando com ela como se fosse mais um atentado aos direitos naturais:

preso [,] foi condenado à morte, obrigado pela lei natural a conservar uma vida que não era da sociedade, mas de Deus, tentava evadir-se quando quiseram prendê-lo de novo para o cadafalso: foi então o seu segundo crime (...), aniquilou ele esse homem que o agarrava pelas costas para sujeitá-lo à pena da lei e isso quando ele estava a entrar no gozo da liberdade pela fuga. O ferimento de Honorato de Bastos tinha pois uma explicação natural. (p. 43)

Desse modo, junto com a promoção da liberdade, a manutenção da vida, como destaca o próprio Nabuco, é um dos componentes centrais da doutrina a que ele recorre para tentar defender o seu constituinte. Basta repisar: "obrigado pela lei natural a conservar uma vida que não era da sociedade, mas de Deus". ${ }^{6}$ E trata-se, diga-se de passagem, de uma defesa eficaz, pois a rejeição sem quartel da escravidão, levada adiante sob a perspectiva do direito natural, torna possível, como já se disse antes, que se obtenha a suspensão da pena de morte e a condenação de Tomás às galés perpétuas.

Este artigo poderia se encerrar por aqui, embora tenha plena consciência de que a maioria das questóes levantadas foi examinada de forma apenas superficial, sem esquecer, inclusive, que o texto em pauta ainda contém outros argumentos cuja abordagem logicamente se faz necessária. Limites de tempo, absolutamente incontornáveis, porém, forçam-me a chegar a uma primeira conclusão. Todavia, não poderia fazê-lo sem chamar a atenção para dois pontos que, pelo seu peso específico, desempenham um papel, não muito evidente, mas, a meu juízo, de grande importância na reflexão de Nabuco.

Refiro-me primeiramente ao fato de que o episódio que aproxima Tomás e Nabuco é detalhado somente no oitavo capítulo do livro, e é examinado por intermédio de um relato quase factual, marcado por uma narrativa curta e ofegante que contrasta sobremaneira com a reflexáo sistemática e erudita, filosófica e juridicamente orientada, que dava o tom do texto até ali. Dá vontade, inclusive, de aproximar esse procedimento da antiga casuística religiosa e forense, que privilegiava o relato minucioso de experiências concretas e frequentemente muito ambíguas — os chamados "casos de consciência” — na expectativa de elucidá-las

\footnotetext{
${ }^{6}$ A obrigação de defender a própria vida como um argumento significativo na tradição do direito natural é discutida no capítulo 3 do livro de Tierney (2001).
} 
pelo recurso a uma determinada tradição: ${ }^{7}$ afinal, basta recordar os assassinatos cometidos pelo escravo Tomás, em seu empenho para salvaguardar tanto a dignidade quanto a própria vida, para que se perceba que enfrentamos aqui uma espécie de situação limite, arriscada e repleta de desafios.

Entretanto, justamente, nem a escravidáo nem a pena de morte parecem suscitar em $\mathrm{Na}$ buco qualquer dubiedade ou hesitação, o que tornaria, em princípio, praticamente desnecessária a alternância entre uma reflexão mais sistemática e a narrativa de um caso controverso e até antinômico, tal como o que encontramos em $A$ escravidão.

Acontece, no entanto, que a consideração de experiências específicas, como a de Tomás, não serve apenas para explicitar dilemas que poderiam ser resolvidos pelo escrutínio e pelo debate da tradição. Além disso, eles podem também apontar para supostos tácitos e mal iluminados desta mesma tradição, convicçóes tão enraizadas que podem até se tornar invisíveis, estimulando portanto uma discussão capaz de permitir alguma renovação em crenças já tão habituais que perigam enferrujar. Com efeito, a minha impressão é a de que é exatamente isto o que acontece em $A$ escravidão, visto que a "anedota", o caso de consciência que aproxima Tomás e Nabuco, torna possível inclusive um melhor entendimento do significado do código criminal do império, em particular no que se refere à escravidáo.

Dessa maneira, creio que o mais correto a ser feito talvez seja precisamente ir direto ao ponto que Nabuco parece querer valorizar e debater: assim como na antiga Roma, onde "uma lei (...) mandava que, quando se desse o assassinato de um senhor por um seu escravo, todos os escravos residentes sob os mesmos tetos fossem mortos, como cúmplices" (p. 37), a legislação brasileira também estipulava penas muito mais severas para os escravos do que para os senhores e o restante da população (p. 36). O sistema penal, desse modo, chegava a reconhecer, ou melhor, a consagrar,

a existência de duas raças entre nós, rivais e inimigas, [o] que fez com que a lei, órgão da vencedora, ou antes da espoliadora, firmasse com uma iníqua sançáo o domínio dessa e marcasse penas infamantes e bárbaras para a outra (Idem). [Os castigos aplicados aos escravos,] assim [,] visariam mais a manter o estado anormal da escravidáo do que a reprimir a espécie do crime, não seriam proporcionais (...) ao delito mas ao perigo iminente da sociedade, não atingiriam só a intençâoo do agente, atingiriam nele toda a sua raça. (Ibidem)

Como em Roma, o que se pretendia não era punir o criminoso, mas prevenir a insurreição.

Nosso bacharel tem, nesta passagem, uma espécie de iluminaçáo schmittiana, e vislumbra, horrorizado, uma sociedade dividida, social e juridicamente, entre amigos e inimigos,

\footnotetext{
${ }^{7}$ Uma avaliação variada e instigante sobre os debates em torno da casuística na Europa moderna pode ser encontrada na coletânea organizada por Leites (1988).
} 
cada qual dominado pelo medo do outro: ao terror dos escravos pelo tratamento que há séculos lhes era dispensado pela classe senhorial, corresponde o receio desta, discreto mas inegável ${ }^{8}$ — sentada que está sobre um barril de pólvora —, em relação à vingança que poderia advir da "raça espoliada".

Mas há mais a ser explorado, até porque — recordemo-nos — ainda resta um segundo e último ponto que deve, no mínimo, ser levantado para que este trabalho possa ser conduzido ao seu final. Refiro-me aqui a uma questão que ocupa boa parte do segundo capítulo de $A$ escravidão, intitulado "A história do crime", o qual, depois de abordar a trajetória da escravidão na antiguidade clássica e no próprio continente africano, vai se deter para estudar, com mais profundidade, a história da implantação e do relativo declínio do comércio de escravos no Brasil. Levando em consideração este contexto, tal questáo diz respeito, especificamente, a maneira pela qual a Inglaterra passa a combater o tráfico no Brasil desde pelo menos 1845, nos marcos do chamado bill Aberdeen, que ao assimilar inteiramente aquele comércio a pirataria, arroga-se o direito de atacar, apresar e eventualmente destruir os navios brasileiros envolvidos neste tipo de atividade.

Esta situação, como se pode imaginar, acaba por colocar Nabuco, não exatamente em um dilema insuperável, mas, até certa medida, em uma posição muito pouco confortável, visto que ele termina por se encontrar, no mínimo, entre dois fogos: ele obviamente não renega a crítica que acabou de fazer ao sistema escravocrata, mas também não pode concordar com a política adotada pela Inglaterra para tentar suprimi-lo. Assim,

depois que seus cruzeiros [deixaram de respeitar a] nossa soberania territorial, depois que na baía do Rio de Janeiro se matou com um tiro de um brigue, o Ganges, sobre a barca Especuladora um tal Bulhōes; depois que a corveta Orestes no mesmo porto fez fogo sobre o vapor Paquete do Sul; depois que súditos nossos foram aprisionados em portos brasileiros; depois que o direito de visita foi exercitado sob as baterias de Santa Cruz; depois que a bandeira nacional içada no brigue de guerra Três de Maio foi ultrajada; depois do desembarque da tripulação armada de um cruzeiro na praia da Armação dos Búzios; depois de outros semelhantes e multiplicados atos de violência praticados pela Inglaterra (p. 88)

Nosso autor, como acabou de ser aludido, não tem nenhuma outra alternativa se não a se pronunciar enfaticamente contra a maneira pela qual o Império Britânico procura conduzir o seu combate ao tráfico de escravos.

\footnotetext{
${ }^{8}$ Sobre este tema, basta consultar, por exemplo, As vítimas algozes (1988), de Joaquim Manuel de Macedo, cuja edição original, sugestivamente, data de 1869, o mesmo ano, não nos esqueçamos, em que Nabuco se envolve com a defesa do "escravo Tomás". Quanto à noção de "iluminação schmittiana", introduzida no início deste parágrafo, quero me referir aos argumentos do jurista alemão Carl Schmitt, para o qual a ideia de política, longe de se resumir ao debate acerca dos assuntos de Estado, sustenta-se na oposição entre duas categorias centrais: amigo $\times$ inimigo (cf. Schmitt, 1976).
} 
Dessa forma, após denunciar o bill Aberdeen como um "ato violento", (p. 83) "ao qual estáo ligadas as mais tristes de nossas recordaçóes" (p. 80), Nabuco passa a discutir o caráter arbitrário e eminentemente despótico desta legislação, posto que a Inglaterra, em função do descumprimento por parte do Brasil do tratado firmado em 1826 entre as duas naçôes, por intermédio do qual o comércio de escravos no Brasil deveria cessar em 1830, até

tinha o direito de fazer-nos a guerra, não tinha, porém, o de usurpar a nossa soberania, o de apoderar-se em nossas águas de navios nossos para ir julgá-los na Europa ou em África. E depois de assim praticar, cobrir o ato com um embuste, a violência com a estipulação de uma convenção, na qual nós nos reserváramos o exercício de nossa soberania, eis o que é desmerecer da grande causa, que tinha chamado a si. A Inglaterra assim procedendo merece bem a apóstrofe eloquente de Sir Thomas Wilde: "A passar semelhante lei, praticais contra um Estado fraco o que não ousais fazer contra uma nação poderosa." (p. 91)

É possível, no entanto, encontrar-se de fato alguma coisa em comum entre o despotismo inerente à escravidão e a posição adotada pela Inglaterra para enfrentá-la, como, de algum modo Nabuco parece indicar? O esforço para responder a esta pergunta deve levar em conta, antes de mais nada, que os casos em pauta dão a impressão de partilhar um mesmo cenário, o mar, ambiente no qual, pela sua mobilidade, inconstância e irregularidade intrínsecas, parece ser extremamente difícil, inclusive na época em que o nosso autor escrevia, a implantação de qualquer legislação mais previsível e estável.

Neste sentido, da mesma maneira que os desertos, creio eu, o mar poderia ser definido, ao contrário da terra firme, como um reino governado pela contingência e pela mais absoluta irregularidade - "um campo livre para a pilhagem", como sugere Carl Schmitt (2014) —, no qual a vontade daqueles que o dominam, tanto os piratas associados ao tráfico quanto os capitães da armada inglesa encarregados da sua eliminação, pode facilmente se expandir sem conhecer nenhum obstáculo. Obcecados pelo enriquecimento pessoal ou pela afirmaçáo da soberania nacional, ambos dão a impressão de deixar de lado qualquer preocupação com o direito natural, a moralidade e a preservação da espécie, reforçando, mesmo involuntariamente - em particular no caso da "Marinha de Sua Majestade" —, o despotismo que $A$ escravidão visa combater.

Como se pode ver, não há uma saída fácil para os problemas sublinhados e enfrentados por Nabuco. Aliás, talvez seja precisamente por esta razão, por esta capacidade de não desviar o olhar diante das ambiguidades e dos paradoxos que povoam o mundo, que ele vai retirar forças, em uma etapa posterior da sua vida, para alterar pouco a pouco a sua personalidade, adicionando uma boa dose de fleugma ao seu temperamento sanguíneo, moderando a veemência e o entusiasmo pela incorporação de uma certa prudência, de tal forma que ele acaba por ganhar condiçôes para se engajar, de maneira intensa e arriscada, mas também bastante efetiva, no combate pela abolição. 


\section{Referências bibliográficas}

ALENCAR, José de. Cartas a favor da escravidão (org. Tâmis Parron). São Paulo: Hedra, 2008.

ALONSO, Angela. Joaquim Nabuco: os salóes e as ruas. São Paulo: Companhia das Letras, 2007.

CARVALHO, José Murilo de. A construção da ordem: a elite política imperial. Teatro de Sombras: a política imperial. Rio de Janeiro: Civilização Brasileira, 2007.

GARNSEY, Peter. Thinking about property. From antiquity to the age of revolution. Cambridge: Cambridge University Press, 2007.

GILSON, Étienne. O espírito da filosofia medieval. São Paulo: Martins Fontes, 2006.

LEITES, Edmund (Org.). Conscience and casuistry in early modern Europe. Cambridge: Cambridge University Press/Paris: Éditions de la Maison de la Science de l'Homme, 1988.

MACEDO, Joaquim Manuel de. As vítimas algozes. Rio de Janeiro: Fundação Casa de Rui Barbosa/São Paulo: Scipione, 1988.

MATTOS, Ilmar Rohloff de. O tempo Saquarema. São Paulo: Editora Hucitec, 2004.

NABUCO, Joaquim. Camões e os Lusíadas. Rio de Janeiro: Tipografia do Imperial Instituto Artístico, 1872.

. Le droit au meurtre. Rio de Janeiro: Garnier, 1872.

. Um estadista do império. 2 vols. Rio de Janeiro: Topbooks, 1997.

. A escravidão. Rio de Janeiro: Nova Fronteira, 1999.

. Minha formação. Rio de Janeiro: Topbooks, 1999.

. O abolicionismo. Rio de Janeiro: Nova Fronteira, 1999.

. Diários: 1873-1910. Recife: Massangana/Bem-te-Vi Produçôes Literárias, 2005.

. Campanha abolicionista no Recife (eleiçôes de 1884). Brasília: Ediçôes do Senado Federal, 2010.

PIETZ, William. Les fétiches. Généalogie d'un problème. Paris: Kargo \& L'Éclat, 2005.

SCHMITT, Carl. The concept of the political. New Jersey: Rutgers University Press, 1976.

. O nomos da Terra no direito das gentes do jus publicum europæum. Rio de Janeiro: Contraponto/Editora PUC-Rio, 2014.

TIERNEY, Brian. The idea of natural rights. Grand Rapids/Cambridge: Wm. B. Eerdman, 2001.

WÉBER, Edouard-Henri. La personne humaine au XIII siècle. Paris: Vrin, 1991. 